\title{
HIGHLIGHT
}

\section{Leptin-induced weight loss is not solely mediated by anorexia}

Jörg Dötsch, Udo Meißner and Wolfgang Rascher

Klinik für Kinder und Jugendliche, Friedrich-Alexander-Universität Erlangen-Nürnberg, Germany

(Correspondence should be addressed to J Dötsch, Department of Pediatrics, Friedrich-Alexander-University Erlangen, Loschgestrasse 15, 91054 Erlangen, Germany; Email: JoergWDoetsch@yahoo.com)

The discovery of the ob-gene product leptin in 1994 $(1-2)$ and the subsequent identification of grossly obese children lacking leptin (3) or its receptor (4) considerably increased the expectation of finding an effective cure for grossly obese humans. Very soon after its discovery it became evident, however, that a deficiency of leptin did not account for obesity in the large majority of patients and the treatment of obese subjects with recombinant leptin was rather disappointing (5). One of the most important reasons for the lack of efficiency of leptin to regulate energy balance in the central nervous system (CNS) of humans is the saturable transport mechanism allowing for (or rather impeding) the penetrance of leptin into the CNS $(6,7)$. Alternative systems involved in the regulation of weight regulation have therefore been sought, such as leptin downstream peptides $(8)$ or mechanisms confined to the regulation of peripheral weight and its metabolic implications (9).

In the last few years, one major focus of leptin research has shifted from central regulation of appetite and energy expenditure to the peripheral actions. Consistent with the cytokine structure of its receptors, the action of leptin has been linked to the proliferation of various tissues leading to effects such as wound healing (10).

However, there is increasing new evidence reviving the role of leptin in weight regulation. It has recently been demonstrated that patients with lipodystrophy have significantly reduced plasma leptin concentrations. Lipodystrophy consists of a heterogeneous group of rare disorders characterized by partial or generalized loss of adipose tissue. The application of leptin reduces hepatic fat mass and improves insulin sensitivity in humans suffering from this condition $(11-13)$.

Direct evidence that leptin directly reduces hepatic lipid synthesis independent of its effect on appetite control now comes from Friedman's group (14). Using transcription profiling they identified the gene most specifically repressed in the liver of leptin-treated $o b / o b$ (i.e. leptin-deficient) mice. It encodes for the stearoyl-CoA desaturase-1 (SCD-1). This iron-containing enzyme catalyses a rate-limiting step in the synthesis of hepatic fatty acids. The principal product of SCD-1 is oleic acid which is formed by desaturation of stearic acid. Therefore SCD-1 is a key enzyme leading to an increase in energy storage (15).
Cohen and co-workers (14) showed that in the leptin-deficient $o b / o b$ mouse leptin treatment completely normalized the elevated SCD-1 gene expression and enzymatic activity. Levels of hepatic monosaturated fatty acids, the products of SCD-1 that were elevated in the leptin-deficient mice, normalized by 12 days of leptin treatment.

In order to distinguish between SCD-1 and non-SCD-1 leptin actions, $o b / o b$ mice were compared with double mutant leptin-deficient $o b / o b$ and SCD-1-deficient $a b^{J} / a b^{J}$ mice. In both male and female double mutant mice, fat mass was reduced to approximately $60 \%$ and lean mass increased by $20-30 \%$ compared with the mice that were only lacking leptin.

Most importantly, it is evident that the effect of leptin on appetite regulation is independent from that on energy expenditure. Double mutant, leptin- and SCD1-deficient mice had an extremely increased food intake, suggesting that the central lack of leptin induces hyperphagia as in the single mutant leptin-deficient $o b / o b$ mice. On the other hand, SCD-1- and leptindeficient mice had an energy expenditure, measured by total and resting oxygen consumption, that was approximately twice as high as in solely leptin-deficient mice. As a sign of increased fatty acid oxygenation, plasma ketone bodies increased significantly in the double mutant mice. As a consequence, hepatic lipid content and triglyceride concentration were significantly reduced in comparison with the SCD-1 active only leptin-deficient $o b / o b$ mice.

These results imply that the weight reducing effect of leptin is predominantly exerted via an increase in energy expenditure through hepatic fatty acid oxygenation. However, Cohen and coworkers report unpublished results showing similar effects on the reduction of SCD-1 activity if leptin is administered into the CNS of wild-type mice. In addition, livers of mice with a liver-specific knock-out of the leptin receptor have normal livers, showing no accumulation of triglycerides (16).

It therefore remains obscure as to what extent the effect of leptin on energy expenditure in rodents is of peripheral nature. As a consequence, an experimental approach using mice with a CNS-specific knock-out of the leptin receptor in order to examine the direct effect of leptin on the hepatic SCD-1 appears to be warranted. 


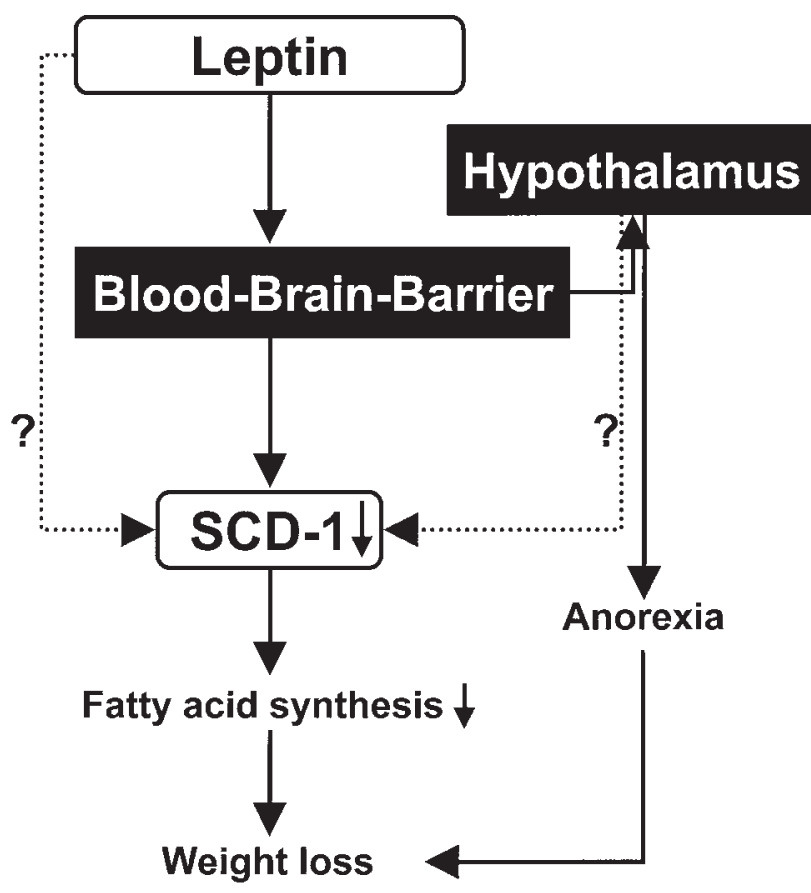

Figure 1 Effect of leptin on weight regulation by inducing anorexia and by reducing hepatic fatty acid synthesis.

Despite the exciting new data by Cohen et al. (14) which discriminate between the mechanisms of the anorectic and the energy expenditure effect of leptin in mice for the first time, the significance of leptin for the reduction of body weight in humans must not be overestimated. This is mainly due to the fact that leptin appears to work more on the central level to induce fatty acid oxygenation. This limits the application of the new findings in the treatment of human obesity. Nonetheless, if the central effect of leptin could be bypassed and hepatic SCD-1 could be suppressed directly, a possible new target site for weight reduction seems to be possible.

In summary, the important new studies by Friedman's group (14) show that suppression of the fatty acid-synthesizing enzyme SCD-1 can correct the hypometabolic phenotype of leptin deficiency, showing that leptin not only works via central anorectic effects but also by increasing hepatic fatty acid oxygenation (Fig. 1).

\section{References}

1 Zhang Y, Proenca R, Maffei M, Barone M, Leopold L \& Friedman JM. Positional cloning of the mouse obese gene and its human homologue. Nature 1994372 425-432.

2 Halaas JL, Gajiwala KS, Maffei M, Cohen SL, Chait BT, Rabinowitz $\mathrm{D}$ et al. Weight-reducing effects of the plasma protein encoded by the obese gene. Science $1995269543-546$.

3 Montague CT, Farooqi IS, Whitehead JP, Soos MA, Rau H, Wareham NJ et al. Congenital leptin deficiency is associated with severe earlyonset obesity in humans. Nature 1997387 903-908.

4 Clement K, Vaisse C, Lahlou N, Cabrol S, Pelloux V, Cassuto D et al. A mutation in the human leptin receptor gene causes obesity and pituitary dysfunction. Nature $1998392398-401$.

5 Heymsfield SB, Greenberg AS, Fujioka K, Dixon RM, Kushner R, Hunt $\mathrm{T}$ et al. Recombinant leptin for weight loss in obese and lean adults: a randomized, controlled, dose-escalation trial. Journal of the American Medical Association $1999 \mathbf{2 8 2}$ $1568-1575$.

6 Schwartz MW, Peskind E, Raskind M, Boyko EJ \& Porte D. Cerebrospinal fluid leptin levels: relationship to plasma levels and to adiposity in humans. Nature Medicine 19962 589-593.

7 Dötsch J, Adelmann M, Englaro P, Dötsch A, Hänze J, Blum WF et al. Relation of leptin and neuropeptide $\mathrm{Y}$ in human blood and cerebrospinal fluid. Journal of Neurological Sciences 1997151 $185-188$.

8 Krude H, Biebermann H, Luck W, Horn R, Brabant G \& Grüters A. Severe early-onset obesity, adrenal insufficiency and red hair pigmentation caused by POMC mutations in humans. Nature Genetics 199819 155-157.

9 Masuzaki H, Paterson J, Shinyama H, Morton NM, Mullins JJ, Seckl JR et al. A transgenic model of visceral obesity and the metabolic syndrome. Science $20012942166-2170$.

10 Frank S, Stallmeyer B, Kampfer H, Kolb N \& Pfeilschifter J. Leptin enhances wound re-epithelialization and constitutes a direct function of leptin in skin repair. Journal of Clinical Investigation 2000 $106501-509$.

11 Oral EA, Simha V, Ruiz E, Andewelt A, Premkumar A, Snell P et al. Leptin-replacement therapy for lipodystrophy. New England Journal of Medicine 2002346 570-578.

12 Petersen KF, Oral EA, Dufour S, Befroy D, Ariyan C, Yu C et al. Leptin reverses insulin resistance and hepatic steatosis in patients with severe lipodystrophy. Journal of Clinical Investigation 2002 109 1345-1350.

13 Oral EA, Ruiz E, Andewelt A, Sebring N, Wagner AJ, Depaoli AM et al. Effect of leptin replacement on pituitary hormone regulation in patients with severe lipodystrophy. Journal of Clinical Endocrinology and Metabolism 200287 3110-3117.

14 Cohen P, Miyazaki M, Socci ND, Hagge-Greenberg A, Liedtke W, Soukas AA et al. Role for stearoyl-CoA desaturase-1 in leptinmediated weight loss. Science 2002297 240-243.

15 Zheng Y, Eilertsen KJ, Ge L, Zhang L, Sundberg JP, Prouty SM et al. Scd1 is expressed in sebaceous glands and is disrupted in the asebia mouse. Nature Genetics 199923 268-270.

16 Cohen P, Zhao C, Cai X, Montez JM, Rohani SC, Feinstein P et al. Selective deletion of leptin receptor in neurons leads to obesity. Journal of Clinical Investigation $2001 \mathbf{1 0 8} 1113-1121$.

Received 4 September 2002

Accepted 5 September 2002 